\title{
PENINGKATAN PENGETAHUAN TENTANG KANKER LEHER RAHIM DAN DETEKSI DINI DENGAN PEMERIKSAAN PAP SMEAR
}

\author{
Knowledge Improvement of Cervical Cancer and Early Detection With Papsmear Test
}

\author{
Devi Usdiana Rosyidah \\ Departemen Farmakologi, Fakultas Kedokteran, Universitas Muhammadiyah Surakarta \\ Korespondensi : Devi Usdiana Rosyidah, email: dur203@ums.ac.id
}

\begin{abstract}
ABSTRAK
Kebanyakan perempuan takut terkena kanker leher rahim, tetapi tidak faham faktor risikonya. Kesadaran melakukan deteksi dini penyakit ini masih terkendala perasaan malu dan biaya yang tidak murah. Jumlah penderita kanker leher rahim di indonesia menempati urutan nomor dua tertinggi didunia. Pemahaman yang benar tentang penyakit ini akan meningkatkan kesadaran melakukan skrining sehingga pencegahan akan lebih mudah dilakukan. Pengabdian masyarakat ini bertujuan memberikan pengetahuan kepada perempuan tentang kanker leher rahim, faktor risiko, cara pencegahan serta skrining kanker leher rahim dengan papsmear langsung bagi peserta tanpa dipungut biaya. Konseling personal dilakukan ke masing-masing peserta setelah hasil pap smear jadi. Jumlah peserta penyuluhan 27 orang, tetapi 4 orang tidak memenuhi syarat dilakukan pap smear, sehingga jumlah peserta pap smear 23 orang. Hasil pap smear: 18 orang normal smear, 2 orang radang ringan, 1 orang radang tidak khas, dan 2 orang radang ringan dengan metaplasi squamosa. Masing-masing peserta telah mengambil hasil dan telah dilakukan konseling personal. Pemahaman yang benar mengenai penyakit kanker leher rahim dan pelaksanaan pap smear dapat menambah data profil kesehatan wanita usia subur khususnya di kabupaten Karanganyar. Peserta pap smear dapat membagikan pengalamannya kepada wanita usia subur lain sehingga tergerak untuk melakukan skrining kanker leher rahim, salah satunya dengan pap smear.
\end{abstract}

Kata kunci : Kanker Leher Rahim, Penyuluhan, Papsmear

ABSTRACT

Cervical cancer has made fear for women, and the knowledge of the risk factors is at a low level. Feeling ashamed and financial hardship are still being the barriers to early detection awareness. Indonesia is the secondranking country worldwide with the highest cervical cancer incidence. The comprehensive knowledge about the disease would increase the awareness of screening. This community service aimed to provide information for the women about cervical cancer, the risk factors, how to do the prevention and screening, and also doing the pap smears. The counseling for each participant was done at different times after the results of the pap smear were established. The number of counseling participants was 27, but 4 participants did not meet the requirements to undergo the pap smears. The results of the pap smears test were 18 participants got normal smears, 2 participants got mild inflammation, 1 participant got nontypical inflammation, and 2 participants got mild inflammation with squamous metaplasia. The comprehensive knowledge about cervical cancer and pap smears test could give the data for the reproductive women health in Karanganyar district. The participants could share their knowledge and experience with other women, so they could be inspired to do the pap smears.

Keywords: Cervical Cancer, Counseling, Pap Smear Test 


\section{PENDAHULUAN}

Angka kejadian kasus kanker leher rahim (kanker servik) di Indonesia mencapai 21 ribu tiap tahunnya. Jumlah ini menempati nomor dua tertinggi di dunia. Pada tahun 2014, lebih dari 92 ribu perempuan Indonesia meninggal karena kanker dengan 10,3 persen di antaranya karena kanker leher rahim. Salah satu pendorong tingginya angka-angka tersebut adalah karena tidak adanya proses pemantauan sejak dini (Nuranna, 2017).

Kanker leher rahim sering tidak menimbulkan gejala dan sulit terdeteksi pada stadium awal dan umumnya baru terdeteksi ketika sudah stadium lanjut. Pada stadium lanjut proses pengobatan yang harus dilakukan menjadi lebih sulit dan biaya pengobatannya pun menjadi lebih mahal. Dibandingkan dengan jenis kanker lainnya, kanker leher rahim sebetulnya paling mudah dicegah dan dideteksi. Maka dari itu skrining kesehatan deteksi dini kanker leher rahim sangat penting dilakukan untuk tindakan pencegahan (Idris, 2017). Cakupan deteksi dini kanker leher rahim dan payudara masih rendah, yaitu sebesar 2,45\%, sehingga memerlukan upaya lebih kuat untuk mencapai target, yaitu deteksi dini terhadap 50\% perempuan usia $30-50$ tahun selama 5 tahun (Wahidin, 2015).

Faktor risiko terjadinya kanker leher rahim antara lain : menikah atau memulai aktifitas seksual pada usia muda (kurang dari 18 tahun), berganti-ganti pasangan seks, sering menderita infeksi di daerah kelamin, wanita yang melahirkan banyak anak, dan wanita yang merokok. Alasan pentingnya deteksi dini kanker leher rahim antara lain : insidensi dan prevalensi cukup tinggi di masyarakat, perkembangan penyakit cukup lama, ada teknik pemeriksaan yang sensitif dan spesifik, ada cara pengobatan yang efektif, dan pemeriksaan bersifat tidak invasif (Sabrida, 2015).

Kejadian kanker leher rahim di wilayah kabupaten karanganyar tahun 2016 terdapat 26 penderita (Dinkes karanganyar, 2016). Di tempat praktik, kami dapatkan beberapa penderita sudah dalam kondisi stadium lanjut, sehingga prognosisnya buruk. Kesadaran untuk mengikuti kegiatan pap smear masih sangat kurang. Beberapa kendalanya antara lain adanya perasaan malu saat di lakukan pemeriksaan pap smear dan besarnya biaya yang cukup merogoh kocek. Selain itu kegiatan ini turut serta dalam 
mendukung program pemerintah untuk deteksi

dini kanker leher rahim di Indonesia.

\section{TUJUAN DAN MANFAAT}

Pengabdian masyarakat ini bertujuan untuk memberi pengetahuan kepada perempuan tentang kanker leher rahim, faktor risiko, cara pencegahannya. Tujuan lain didapatkan data skrining kanker leher rahim dari kegiatan pap smear langsung bagi peserta tanpa di pungut biaya.

\section{METODE PELAKSANAAN}

Metode kegiatan pengabdian masyarakat yang dilakukan adalah kegiatan penyuluhan kesehatan dengan tema "Waspada kanker leher rahim" kemudian dilanjutkan pemeriksaan pap smear secara bergilir di ruang periksa. Kegiatan pap smear bekerjasama dengan Laboratorium klinik dan hasil pemeriksaan papsmear kemudian dikirim serta dibacakan oleh dokter spesialis patologi anatomi. Pada lain waktu dilakukan konseling hasil pemeriksaan pap smear pada peserta secara personal.

\section{HASIL PELAKSANAAN KEGIATAN}

Tabel 1. Hasil pap smear peserta

\begin{tabular}{clccc}
\hline \multirow{2}{*}{ No } & \multicolumn{1}{c}{ Hasil Papsmear } & \multicolumn{2}{c}{ Rentang Usia (tahun) } & Jumlah \\
\cline { 3 - 4 } & & Terendah & Tertinggi & \\
\hline 1 & Papanicolaou Klas I Normal Smear & 27 & 58 & 18 orang \\
2 & Papanicolaou Klas I Radang ringan & 34 & 54 & 2 orang \\
3 & Papanicolaou Klas I Radang Tidak khas & 48 & - & 1 orang \\
4 & Papanicolaou Klas I Radang ringan dengan metaplasi & 42 & 52 & 2 orang \\
\hline
\end{tabular}

Dari Tabel 1, didapatkan data bahwa dari 23 peserta, hasil pap smear sebagai berikut : 18 orang dengan hasil normal smear, 2 orang dengan hasil radang ringan, 1 orang dengan hasil radang tidak khas, dan 2 orang dengan hasil radang ringan dengan metaplasi squamosa. Masing-masing peserta telah mengambil hasil pap smear dan telah dilakukan konseling personal sesuai dengan hasil pap smear, termasuk rencana pemeriksaan ulang pap smear bagi peserta terutama yang hasil papsmear ada catatan.

Tingginya insiden kanker servik dapat dikaitkan dengan kurangnya kesadaran masyarakat, kurangnya program skrining yang efektif dan pelaporan kasus yang terintegratif. Penyakit lanjutan dari kanker servik melibatkan beban keuangan yang tinggi, pilihan perawatan 
yang terbatas, stres, kehilangan keluarga dan kematian yang lebih tinggi (Bhattacharyya et al., 2015).

Kejadian kanker servik bagian dari mimpi buruk di masyarakat, yang hal ini dapat kita cegah dengan menciptakan kesadaran dan menerapkan program skrining yang efektif sebagai tindakan kesehatan masyarakat (Bhattacharyya et al., 2015). Pengenalan penyakit kanker penting dilakukan untuk menciptakan kesadaran dan menurunkan kasus baru kanker. Pengenalan ini selanjutnya diperlukan tindakan pencegahan dan deteksi dini (Pusdatin, 2015).

Pap smear merupakan tindakan sederhana, non invasif, lebih spesifik dan mudah untuk mendeteksi lesi prekanker (Sachan et al., 2018; Bhattacharyya et al., 2015). Bal et al., (2012) menjelaskan pap smear dengan melihat sitologi servik metode Papanicolaou efektif untuk skrining kondisi kelainan servik jenis premaligna dan maligna (keganasan). Kegiatan pap smear sebaiknya dilanjutkan dengan konsultasi kesehatan (Mitteldorf, 2016).

Menilik dari biaya pap smear yang sampai angka ratusan ribu, di Indonesia angka sekian masih menjadi beban bagi masyarakat menengah kebawah sehingga enggan untuk periksa. Maka kegiatan serupa menjadi impian masyarakat untuk mendapatkan layanan kesehatan terutama pencegahan kejadian kanker servik

Lanjutan dari kegiatan ini diharapkan para peserta pap smear mendapatkan pemahaman yang lebih baik mengenai kanker leher rahim, faktor risiko, dan cara pencegahannya. Selain itu peserta dapat menularkan pengalamannya dan menjadi pionir di masyarakat untuk mengajak wanita usia subur lain mengikuti kegiatan yang serupa. Sedangkan hasil skrining kanker leher rahim ikut mendukung kegiatan pemerintah dalam layanan kesehatan berupa kegiatan promotif preventif.

\section{SIMPULAN DAN SARAN}

Dari hasil tersebut dapat disimpulkan bahwa pemahaman yang benar mengenai penyakit kanker leher rahim dan pelaksanaan pap smear dapat menambah data profil kesehatan perempuan usia subur di kabupaten Karanganyar. Selain itu peserta pap smear dapat menularkan pengalamannya kepada perempuan usia subur lain sehingga tergerak untuk melakukan skrining kanker leher rahim, salah satunya dengan pap smear. 


\section{DAFTAR PUSTAKA}

Bal, M. S., Goyal, R., Suri, A. K., and Mohi, M. K. 2012. Detection of abnormal cervical cytology in Papanicolaou smears. $J$ Cytol. 29(1): 45-47.

Bhattacharyya, A. K., Nath, J. D., and Deka, H. 2015. Comparative study between pap smear and visual inspection with acetic acid (via) in Skrining of CIN and early cervical cancer. $J$ Midlife Health. 6(2): 53-58.

Dinkes Karanganyar, 2016. Profil Kesehatan Kabupaten Karanganyar Tahun 2016. http://www.depkes.go.id/resources/dow nload/profil/PROFIL KAB KOTA 201 6/3313 Jateng_Kab_Karanganyar_2016 .pdf

Idris, F. 2017. BPJS Kesehatan Kembali Gelar Pemeriksaan IVA di Karanganyar. https://bpjskesehatan.go.id/bpjs/dmdocuments/60d7 b91175f673d2b408bbf74e30fb5d.pdf

Mitteldorf, C. A. T. S. 2016. Cervical cancer Skrining: from Pap smear to future strategies. J. Bras. Patol. Med. Lab. 52(4)

Nuranna, L. 2017. Jumlah Kasus Kanker Serviks Indonesia Tertinggi ke-2 di Dunia. https://www.cnnindonesia.com/gayahidup/20170827161551-255237610/jumlah-kasus-kanker-serviksindonesia-tertinggi-ke-2-di-dunia

Pusdatin. 2015. Situasi Penyakit Kanker. Buletin Jendela Data \& Informasi Kesehatan, Semester 1.

Sabrida, H. 2015. Peranan Deteksi Dini Kanker untuk Menurunkan Penyakit Kanker "Stadium Lanjut. Buletin Jendela Data \& Informasi Kesehatan, Semester 1.

Sachan, P. L. , Singh, M., Patel, M. L., and Sachan, R. 2018. A Study on Cervical Cancer Skrining Using Pap Smear Test and Clinical Correlation. Asia Pac J Oncol Nurs. 5(3): 337-341.

Wahidin, M. 2015. Deteksi Dini Kanker Leher Rahim dan Kanker Payudara di Indonesia. Buletin Jendela Data \& Informasi Kesehatan, Semester 1. 